\title{
ПРОБЛЕМИ ВИКЛАДАННЯ НАВЧАЛЬНОЇ ДИСЦИПЛІНИ "КЛІНІЧНА ЛАБОРАТОРНА ДІАГНОСТИКА" СТУДЕНТАМ ФАКУЛЬТЕТУ ПІДГОТОВКИ ІНОЗЕМНИХ ГРОМАДЯН
}

\section{О.І. Данилюк}

\author{
Івано-Франківський національний медичний університет, кафедра клінічної фармакології \\ і фармакотерапії, м. Івано-Франківськ, Україна, \\ ORCID ID: 0000-0002-4334-4300, \\ e-mail: oxanadanylyuk@gmail.com
}

Резюме. Залучення на навчання іноземних громадян є запорукою розвитку вищих навчальних закладів України. На світовому ринку вищої освіти для України наразі склалася вдала ситуація щодо співвідношення вартості та якості освіти, що є провідним критерієм у виборі місця навчання. Інтернаціоналізація сучасної вищої освіти зумовлює проблему адаптації іноземних студентів до нового мовного, соціального та навчального середовища. Створення умов для отримання якісної освіти іноземцями в Україні безперечно сприятиме покращенню іміджу нашої країни, Проте слід зазначити, що організація їх успішного навчання потребує більшої уваги. У статті розглянуто особливості надання освітніх послуг у вищих навчальних закладах України для студентів-іноземців. Проаналізовано особливості національної освіти та спектр студентів-іноземців залежно від національності. Доведено важливість дисципліни "Клінічна лабораторна діагностика" у виборі майбутньої спеціальності студентами у вищих навчальних медичних закладах. Наведено особливості проведення і оцінювання дисципліни "Клінічна лабораторна діагностика" на кафедрі клінічної фармакології і фармакотерапії ІваноФранківського національного медичного університету для студентів за фаховим напрямком «Фармація, промислова фармація». Визначено засоби проведення практичних занять та самостійної роботи студентів із дисципліни, наведено тематику лекційного матеріалу. Комплексне застосування новітніх інформаційних та педагогічних технологій дозволяє суттєво підвищити рівень підготовки фахівців із числа іноземних громадян. Нормативні дисципліни у студентів-іноземців формують освітньо-кваліфікаційний досвід та раціонально націлюють на вибір майбутньої спеціальності.

Ключові слова: іноземні студенти, фармація, лабораторна діагностика.

Вступ. У сучасних умовах інтернаціоналізації вищої освіти, Україна ввійшла до світового освітньо-наукового простору як повноправний партнер. Для здійснення стратегічного курсу України на інтеграцію до Європейського Союзу основними напрямами культурно-освітньої та науково-технічної інтеграції визначено впровадження європейських норм і стандартів в освіті, науці й техніці, поширення власних культурних і науково-технічних здобутків у європейській спільноті. За останні роки актуальним стало питання організації навчання іноземних громадян в Україні [3]. Як відомо, щорічно вищі навчальні заклади (ВН3) України приймають студентів з понад 150 країн світу. Така тенденція обумовлено тим, що наша держава надає широкий спектр освітніх послуг. Таким чином іноземні студенти мають можливість навчатися більш, ніж у 240 ВН3, здобувати освіту українською, російською та англійською мовами, а також вільно вибирати спеціальність. Приваблює іноземних студентів і вартість навчання та проживання. Українські університети мають хорошу репутацію у світі, яка постійно виходить на новий рівень завдяки інноваційним науковим та практичним відкриттям як студентів, так і викладачів. Наша держава демонструє позитивну динаміку приросту щодо залучення іноземних студентів. Кількість студентів-іноземців на сьогодні становить понад 66310 осіб [9, 2]. При цьому, починаючи з 2011 року, число студентів- іноземців збільшилось на понад 13 тисяч осіб. Серед країн, громадяни яких обирають для навчання Україну, найчастіше зустрічається Індія - 16,4 \%, Азербайджан - 11,3 \%, Марокко - 8,8 \%, Туркменістан $6,7 \%$, Нігерія - 4,9 \%, Грузія - 4,2 \%, Туреччина $4,1 \%$, Сгипет - 3,8 \%, Узбекистан - 3,5 \%, Йорданія $3,2 \%$ та інші країни $-33,1 \%$ [8].

Підготовка фахівців у галузі «Медицина» із числа іноземних громадян з високим рівнем практичної та професійної компетентності є одним із важливих чинників подальшого розвитку навчального закладу в напрямку інтеграції у міжнародний освітній простір [4]. При цьому важливим є застосування комплексного підходу до організації освітнього процесу 3 відповідним програмним і технічним забезпеченням, який, зокрема, дає можливість максимально мінімізувати вплив суб'єктивних чинників, домогтися об'єктивності проведення оцінювання знань і вмінь [5].

Навчання іноземних громадян в ІваноФранківському національному медичному університеті (ІФНМУ) проводиться з 1992 року. На той момент навчалося не більше двадцяти студентів, які були вихідцями з Росії, Румунії, Пакистану та Камеруну. Починаючи 32002 року кількість студентівіноземців значно зростала, і вже в 2010 році на факультеті навчалося 857 осіб, а в 2018 їх кількість склала 1423 іноземні громадяни. На даний момент в ІФНМУ 
навчаються студенти 346 країн світу, серед яких $є$ Азербайджан, Алжир, Болгарія, Ботсвана, Великобританія, Габон, Гана, Греція, Данія, Еквадор, Замбія, Зімбабве, Індія, Ірак, Іран, Іспанія, Йорданія, Камерун, Канада, Кенія, Конго, Лесото, Ліберія, Ліван, Лівія, Мальдіви, Марокко, Намібія, Нігерія, Німеччина, Пакистан, Палестина, Польща, Російська Федерація, Руанда, Румунія, Саудівська Аравія, Сирія, Сінгапур, США, Сьєрра-Леоне, Туніс, Туркменістан, Угорщина, Узбекистан [11].

Завданням будь-якого ВН3, незалежно від національності студента, $є$ необхідність підготовки фахівця високого рівня, що можливо лише за умови успішної інтеграції студента в нове навчальне середовище. Фахова підготовка іноземних студентів $\epsilon$ дещо специфічною та включає в себе врахування попереднього досвіду, надання студентам-іноземцям знань, які дозволятимуть їм набувати умінь самостійно працювати, поетапне ознайомлення студентів зі змістом фахової діяльності, міжпредметна координація дисциплін загальноосвітнього циклу з урахуванням індивідуальних знань, диференційований підхід до навчального процесу, взаємодія викладачів фахових дисциплін 3 викладачами мовної підготовки для створення нового навчального матеріалу, що сприятиме комфортному засвоєнню навчальної інформації; полікультурна компетентність викладацького складу [1].

Важливим для студентів є засвоєння нормативних фахових дисциплін, які налаштують на професійну орієнтацію в майбутній спеціальності.

Так, на кафедрі клінічної фармакології і фармакотерапії Івано-Франківського національного медичного університету для студентів-іноземців для забезпечення навчального процесу запропонована i введена в навчальний процес дисципліна «Лабораторна діагностика» за фаховим напрямком 226 «Фармація», «Промислова фармація». Дана дисципліна вивчається на четвертому курсі та передбачає 16 годин лекцій, 30 годин практичних занять та 44 години самостійної роботи студентів, що відповідно до загальної кількості кредитів СКТС складає 3 кредити. Дисципліна грунтується на основі програми з лабораторної діагностики, затвердженої на центральній методичній комісії з вищої медичної освіти МO3 України, навчального плану підготовки фахівця освітньо-кваліфікаційного рівня «спеціаліст» кваліфікації «провізор» у вищих навчальних закладах МО3 України за спеціальністю 226 "Фармація, промислова фармація" кваліфікації освітньої «Магістр фармації» [6].

Структура залікового кредиту дисципліни включає в себе два змістові модулі: «Вступ до лабораторної діагностики. Лабораторні методи дослідження крові, сечі, мокротиння» та «Методи дослідження шлунково-кишкового тракту. Вплив лікарських препаратів на лабораторні показники»

Кількість лекцій дисципліни передбачає 16 годин; на кожну лекцію відведено по дві години. Тематика лекцій включає в себе клініко-лабораторні показники як критерії ефективності та безпеки лікарської терапії, дослідження системи крові, загальні відомості про склад крові та кровотворення, гематологічна характеристика анемій; порушення лейкопое- зу: лейкози, лейкопенії, лейкоцитоз, агранулоцитоз, лейкоцитарна формула, типові зміни лейкоцитарної формули при найбільш поширених захворюваннях внутрішніх органів; поняття про зсідальну і антизсідальну властивості крові, коагулограму, групи крові, біохімічні дослідження: білки і білкові фракції, показники азотистого, ліпідного, вуглеводневого, пігментного обміну; загальні властивості сечі, клінічний аналіз сечі, методи визначення в сечі білка, цукру, кетонових тіл, білірубіну, мікроскопія сечових осадків; склад і види мокротиння, макро- і мікроскопічне вивчення мокротиння, діагностичне значення мокротиння в пульмонології, дослідження транссудатів i ексудатів; клінічне дослідження шлункового і дуоденального вмісту, дослідження копрограми; вплив лікарських препаратів на результати клініколабораторного дослідження. Робочою програмою передбачено 13 практичних занять та модульний контроль. На самостійну позааудиторну роботу відведено 44 години, що передбачає детальне вивчення морфологічної структури формених елементів, імуноферментні методи вивчення гемопоетичних клітин, мієлограму, дослідження рідин з серозних порожнин, вивчення дуоденального вмісту, діагностичне значення дослідження шлункового соку, методи визначення реакції сечі, білка, цукру, кетонових тіл, жовчних пігментів; діагностика гельмінтозів; функціональні фармакологічні проби.

Поточний контроль змістових модулів сумарно складає 120 балів. Підсумковий модульний контроль (залік) - контроль практичних умінь, контроль теоретичних знань та інше - складає 80 балів. Загальний рейтинг 3 модулю дисципліни не перевищує 200 балів. Підсумковий модуль вважається складеним, якщо студент набрав від 120 балів до 200 балів.

Поточний контроль засвоєного матеріалу 3 дисципліни включає відповідь на два теоретичні питання (максимум 4 бали, мінімум 2 бали); вирішення ситуаційної задачі або оцінка аналізу лабораторного дослідження (максимум 2 бали, мінімум 1 бал); тестовий контроль (максимум 3 бали, мінімум 2 бали). При засвоєнні теми за традиційною системою студенту присвоюються бали: максимально - 9 балів; мінімально - 5 балів.

Максимальна кількість балів за поточну навчальну діяльність студента складає 117 , мінімальна 65. Студент допускається до підсумкового модульного контролю при виконанні умов навчальної програми і кількості балів за поточну діяльність не менше 65.

Оцінювання самостійної роботи студентів, яка передбачена в темі поряд з аудиторною роботою, здійснюється під час поточного контролю теми на відповідному аудиторному занятті. Оцінювання тем, які виносяться лише на самостійну роботу і не входять до тем аудиторних навчальних занять, контролюється при підсумковому модульному контролі. Додаткові 3 бали можна отримати за рахунок написання реферату. Підсумковий модульний контроль 3 лабораторної діагностики проводиться в кінці семестру. До нього допускаються студенти, які виконали навчальний план та набрали не менше 65 балів за поточну навчальну роботу [6]. 
Важливим чинником інтенсифікації процесів інтернаціоналізації вищої освіти в Україні є співпраця з іноземними партнерами та відповідна комунікація. Український державний центр міжнародної освіти здійснює координуючу функцію в процесі відбору та навчання іноземних студентів.

Спільні освітні або науково-дослідницькі програми, навчання іноземних студентів є не лише факторами, що демонструють науковий та освітній потенціал, рівень міжнародних зв'язків, привабливість країни як такої, це ще й вагома інвестиція у власне майбутнє та конкурентоздатність.

Висновки. Комплексне застосування новітніх інформаційних та педагогічних технологій дозволяє суттєво підвищити рівень підготовки фахівців із числа іноземних громадян. Нормативні дисципліни у студентів- іноземців формують освітньокваліфікаційний досвід та раціонально націлюють на вибір майбутньої спеціальності.

\section{References:}

1. Amirov AF, Amirova LA. Sistema professionalnoy sotsializatsii studentov $\mathrm{v}$ vysshey shkole. Pedagogika. 2014; 7:44-48.

2. Bulgakova NB, Dovgodko TI, Dichenko TV, Chaychenko NN. Didaktika dovuzivskoï pidgotovki studentiv-inozemtsiv: navchal'no-metodichniy posibnik Sumi: Sums'kiy derzhavniy universitet. 2017. P.286.

3. Verbitska A. Strategii internatsionalizatsiï vishchoï osviti vonteksti zabezpechennya konkurentospromozhnosti natsional'noï osvitnoï modeli IV mizhnarodna naukovo-metodichna konferentsiya «Aktual'ni pitannya organizatsiï navchannya inozemnikh studentiv v Ukraïni; 2018 trav 2-4; Ternopil; 2018. P.6768.

4. Klishch GI. Formi organizatsiï i navchannya $u$ medichnikh universitetakh Avstriï Medichna osvita. 2014; 4:56-59.

5. Maksimenko SD, Filonenko MM. Pedagogika vishchoï medichnoï osviti Tsentr uchbovoï literaturi. 2014. P.288.

6. MOZ Ukraïni Vishchiy derzhavniy navchal'niy medichniy zaklad Ukraïni Ivano-Frankivs'kiy natsional'niy medichniy universitet. Kafedra klinichnoï farmakologiï i farmakoterapiï. Navchal'no-metodichniy kompleks do zabezpechennya navchal'nogo protsesu $\mathrm{z}$ vibirkovoï distsiplini «Laboratorna diagnostika» za fakhovim napryamkom farmatsiya, promislova farmatsiya -226. 2019. P.3-18.

7. Semenennko IC. Osoblivosti fakhovoï pidgotovki inozemnikh studentiv vishchikh tekhnichnikh navchalnikh zakladiv. Praktika organizatsiïpedagogichnogo protsesu. 2014; 2:33-36.

8. Soloshchenko VM. Internatsionalizatsiya vishchoï osviti: poglyad anglomovnogo suspil'stva Visnik Cherkaskogo universitetu. Seriya pedagogichni nauki.2017; 12:99-103.

9. Informatsiyniy resurs https://www.ifnmu.edu.ua
УДК 378.147+616-071+614.253.4

ПРОБЛЕМЫ ПРЕПОДАВАНИЯ УЧЕБНОЙ

ДИСЦИПЛИНЫ "КЛИНИЧЕСКАЯ ЛАБОРА-

ТОРНАЯ ДИАГНОСТИКА" СТУДЕНТАМ

ФАКУЛЬТЕТА ПОДГОТОВКИ

ИНОСТРАННЫХ ГРАЖДАН

\section{О.И. Данилюк}

Ивано-Франковский национальный медиџинский университет, кафедра клинической фармакологии и фармакотерапии, 2. Ивано-Франковск, Украина, ORCID ID: 0000-0002-4334-4300,

e-mail: oxanadanylyuk@gmail.com

Резюме. Привлечение на обучение иностранных граждан является залогом развития высших учебных заведений Украины. На мировом рынке высшего образования для Украины сейчас сложилась удачная ситуация относительно соотношения стоимости и качества образования, что является ведущим критерием в выборе места обучения. Интернационализация современного высшего образования предопределяет проблему адаптации иностранных студентов к новой языковой, социальной и учебной среде. Создание условий для получения качественного образования иностранцами в Украине бесспорно будет способствовать улучшению имиджа нашей страны, однако, следует отметить, что организация их успешного обучения требует большего внимания. В статье рассмотрены особенности предоставления образовательных услуг в высших учебных заведениях Украины для студентов-иностранцев. Проанализированы особенности национального образования и спектр студентов-иностранцев в зависимости от национальности. Доказана важность дисциплин "Клиническая лабораторная диагностика" в выборе будущей специальности студентами в высших учебных медицинских заведениях. Приведены особенности проведения и оценки дисциплины "Клиническая лабораторная диагностика» на кафедре клинической фармакологии и фармакотерапии Ивано-Франковского национального медицинского университета для студентов по профессиональному направлению фармация, промышленная фармация. Определены способы проведения практических занятий и самостоятельной работы студентов по дисциплине, приведена тематика лекционного материала. Комплексное применение новейших информационных и педагогических технологий позволяет существенно повысить уровень подготовки специалистов из числа иностранных граждан. Нормативные дисциплины у студентов-иностранцев формируют образовательно-квалификационный опыт и рационально нацеливают на выбор будущей специальности.

Ключевые слова: иностранные студенты, фармация, лабораторная диагностика. 
UDC 378.147+616-071+614.253.4

PROBLEMS REGARDING DISCIPLINE "CLINICAL AND LABORATORY DIAGNOSTICS" TEACHING FOR THE FOREIGN CITIZENS TRAINING FACULTY STUDENTS

\section{O.I. Danyliuk}

Ivano-Frankivsk National Medical University, department of clinical pharmacology and pharmacotherapy, Ivano-Frankivsk, Ukraine, ORCID ID: 0000-0002-4334-4300,

e-mail: oxanadanylyuk@gmail.com

Abstract. Attracting foreign students to studying is a key to the development of higher education institutions in Ukraine. The global market for higher education in Ukraine is currently in a good balance between the cost and quality of education, which is a leading criterion for choosing a place of study. The internationalization of modern higher education causes the problem of adaptation of foreign students to the new linguistic, social and educational environment. Creating conditions for quality education by foreigners in Ukraine will undoubtedly help to improve the image of our country. However, it should be noted, that the organization of their successful education requires more attention. It is of great importance to apply a comprehensive approach to the organization of educational process with appropriate software and technical provision, which, in particular, allows to minimize the impact of subjective factors, to achieve objectivity in the assessment of knowledge and skills. The article deals with the peculiarities of providing educational services in higher educational establishments of Ukraine for foreign students. The specifics of national education and the range of foreign students depending on nationality are analyzed. The importance of discipline "Clinical and laboratory diagnostics" in the choice of the future specialty by students in higher educational establishments has been proved. The peculiarities of conducting and evaluation of the discipline "Clinical and laboratory diagnostics" at the department of Clinical pharmacology and pharmacotherapy at Ivano-Frankivsk National Medical University for pharmacy, industrial pharmacy specialty students are given. The means of conducting practical classes and independent work of students in the discipline are defined, the topics of the lecture material are given. This discipline is taught in the fourth year and provides 16 hours of lectures, 30 hours of practical classes, and 44 hours of independent student work, which is 3 credits according to the total ECTS. The discipline is based on the program of laboratory diagnostics, approved by the Central Methodological Commission on Higher Medical Education of the Ministry of Health of Ukraine, the curriculum of training for educational qualification "specialist" and "pharmacist" in higher educational institutions of the Ukraine Ministry of Health, specialty 226 "Pharmacy" educational qualification "Master of Pharmacy". The structure discipline credit includes two semantic modules: «Introduction to laboratory diagnostics. Laboratory blood, urine, sputum testing and research methods for gastrointestinal tract. Effect of drugs on laboratory parameters». The number of lectures in the discipline provides 16 hours, two hours each. Current control of content modules is a total of 120 points. Total module control (credit) - control of practical skills, control of theoretical knowledge - is rated 80 points. The total rating of the module does not exceed 200 points. The final module is considered to be completed if the student has scored from 120 points to 200 points. The complex application of the latest information and pedagogical technologies allows to significantly increase the level of foreign citizens training. The normative disciplines for foreign students form educational qualification experience and rationally aim at the choice of a future specialty.

Keywords: foreign students, pharmacy, laboratory diagnostics. 